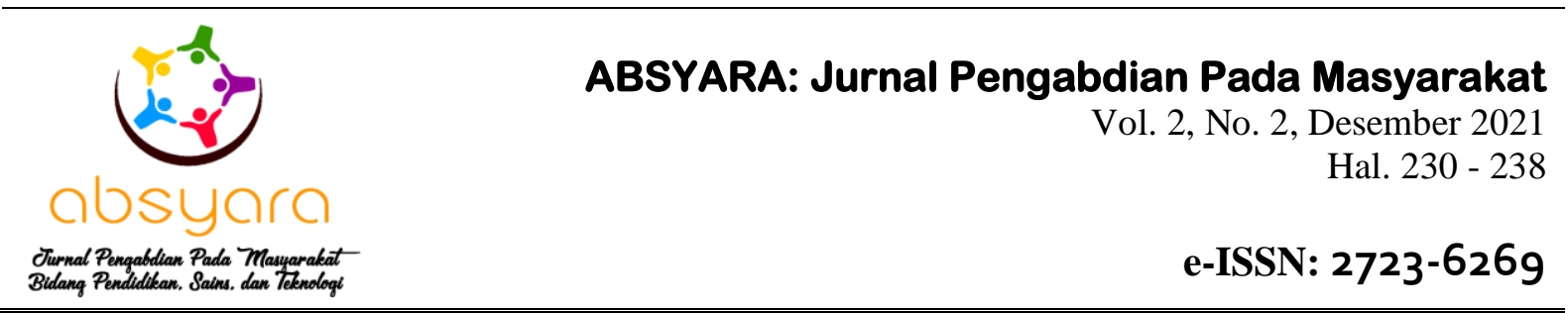

\title{
Pelatihan Pemanfaatan Teknologi Sebagai Media Pendukung Pembelajaran Untuk Guru di Kecamatan Sembalun
}

\author{
Baiq Andriska Candra Permana ${ }^{* 1}$, Hariman Bahtiar², Aswian Editri Sutriandi ${ }^{3}$, \\ Muhammad Djamaluddin ${ }^{4}$, Suhartini ${ }^{5}$ \\ andriska.cp@ gmail.com ${ }^{* 1}$ \\ 1,4,5Teknik Informatika,Universitas Hamzanwadi \\ ${ }^{2,3}$ Sistem Informasi, Universitas Hamzanwadi
}

Received: 30 October 2021 Accepted: 07 December 2021 Online Publisher: 30 December 2021 DOI: 10.29408/ab.v2i2.4210

\begin{abstract}
Abstrak: Keterlibatan dosen, mahasiswa dan tenaga pendidik merupakan suatu bentuk integral Tri Dharma perguruan tinggi. Pendidikan memiliki peran yang sangat penting dan menjadi kunci utama untuk menghasilkan sumber daya manusia yang berkualitas. Dalam praktik kegiatan belajar mengajar saat ini, masih banyak guru yang belum menggunakan media atau teknologi dalam mengajar. Oleh sebab itu perlu adanya upaya peningkatan kompetensi guru melalui Kegiatan Pengabdian Masyarakat (PKM) sehingga para guru dapat beradaptasi dengan era industri 4.0 yang lebih cenderung memanfaatkan teknologi di berbagai bidang dalam kehidupan salah satunya dunia pendidikan. Kegiatan PKM dilaksanakan untuk 6 desa di Kecamatan Sembalun dengan tujuan memeratakan kompetensi para guru yang berada di desa agar setara dengan guru yang berada di kota dalam menyajikan media pembelajaran berbasis teknologi. Pelatihan pembuatan media pembelajaran interaktif ini dipilih untuk menghasilkan suatu pembelajaran menarik berbasis visual dan grafis sehingga pembelajaran menjadi lebih menarik dan tidak membosankan. Dengan dilaksanakannya kegiatan ini para guru memiliki kompetensi lebih dalam pemanfaatan teknologi dan telah berhasil membangun media pembelajaran sendiri. Selain dari pada itu kreativitas guru menjadi meningkat dengan adanya kegiatan ini.
\end{abstract}

Kata kunci: Kompetensi Guru; Media Pembelajaran; Pemanfaatan Teknologi

\begin{abstract}
The involvement of lecturers, students, and teaching staff is an integral form of the Tri Dharma of higher education. Education has a crucial role and is the primary key to producing quality human resources. In the current practice of teaching and learning activities, many teachers have not used media or technology in teaching. Therefore, it is necessary to increase teacher competence through Community Service Activities to adapt to the industrial era 4.0, which is more likely to use technology in various fields of life, one of which is the world of education. PKM activities were carried out for six villages in Sembalun District to equalize the competence of teachers in the village so that they were equal to teachers in the city in presenting technology-based learning media. This interactive learning media creation training produced enjoyable visual and graphic-based learning to become more exciting and not dull. With the implementation of this activity, teachers have more competence in using technology and have succeeded in building their learning media. Apart from that, the creativity of the teacher increases with this activity.
\end{abstract}

Keywords: Learning Media; Teacher Competence; Technology Utilization 
Permana, B. A. C., Bahtiar, H., Sutriandi, A. E., Djamaluddin, M., Suhartini, S. (2021). Pelatihan pemanfaatan teknologi sebagai media pendukung pembelajaran untuk guru di Kecamatan Sembalun. ABSYARA: Jurnal Pengabdian Pada Masyarakat, 2(2), $230-238$. Doi: $10.29408 / a b . v 2 i 2.4210$

\section{PENDAHULUAN}

Dunia pendidikan saat ini telah mengalami berbagai perubahan yang cukup signifikan di berbagai bidang, terutama perubahan tersebut pada bidang teknologi informasi. Hal tersebut berdampak terhadap bergesernya proses pembelajaran yang diterapkan pada dunia pendidikan yang semula bersifat manual dan saat ini secara perlahan terus berkembang ke arah digital (Myori, dkk., 2019). Tujuan dari suatu pendidikan nasional adalah untuk melakukan peningkatan terhadap sumber daya manusia yang berkualitas (Wardinur \& Mutawally, 2019). Terlebih dimasa pandemi seperti saat ini, pemanfaatan teknologi dan internet sangat diperlukan untuk dapat terus melaksanakan kegiatan belajar mengajar jarak jauh baik menggunakan video call, Whatsapp, personal chat dan lainnya (Elizabeth, dkk., 2021).

Pada praktik kegiatan belajar mengajar saat ini, masih banyak para guru yang belum memanfaatkan media maupun teknologi dalam mengajar (Wijaya \& Ferdinandus, 2020). Padahal untuk era saat ini para peserta didik cenderung kurang antusias untuk mengikuti kegiatan belajar dengan sistem klasik. Seorang guru harus memiliki kompetensi sebagaimana Permen Dikbud nomor 16 tahu 2007 yang meliputi sosial, pedagogi, kepribadian dan profesional (Sutisna, dkk., 2020). Para pengajar khususnya para guru sekolah harus mampu beradaptasi perkembangan teknologi yang ada di era digital saat ini dengan cara tetap melakukan pembaharuan terhadap kompetensi yang dimiliki sehingga dapat mengikuti perkembangan teknologi saat ini yang lebih dikenal sebagai era industri 4.0 (Kholisho, dkk., 2021) . Sehingga dengan kompetensi yang dimiliki, guru dapat melakukan proses kegiatan belajar mengajar sesuai dengan perkembangan zaman (Miftah, 2014).

Sebagaimana pengabdian yang sebelumnya juga pernah dilakukan oleh (Soemantri, 2019) yaitu melakukan pelatihan pembuatan media pembelajaran digital karena dianggap penting dalam suatu proses pembelajaran. Materi yang disampaikan oleh pengajar akan lebih mudah tersampaikan pada peserta didik. Selain itu pada pengabdian yang dilakukan oleh (Samsuri, dkk., 2020) melakukan pelatihan membuat media pembelajaran interaktif untuk guru biologi mengingat dimasa pandemi banyak sekolah yang diliburkan, sehingga untuk tetap menunjang pembelajaran walaupun harus dilakukan secara online dari rumah harus ada media interaktif sehingga penyampaian guru menjadi lebih mudah dipahami walau tanpa harus bertatap muka.

Pelatihan pembuatan media pembelajaran interaktif ini dipilih juga berdasarkan pertimbangan pemanfaatan teknologi dengan tampilan visual berupa grafik dan gambar yang menarik dapat menarik minat para peserta didik untuk lebih tertarik untuk mengikuti pelajaran dan membantu para guru untuk mendukung kegiatan belajar mengajar.

\section{METODE PELAKSANAAN}

\section{Waktu dan tempat}

Kegiatan ini dilaksanakan pada bulan Agustus 2021 berlokasi di Ruang kelas SMP 1 Sembalun dengan seizin kepala sekolah setempat. Kegiatan ini secara keseluruhan dihadiri oleh guru perwakilan kecamatan Sembalun yang terdiri atas 6 Desa meliputi Desa Sajang, Desa Sembalun, Desa Sembalun Lawang, Desa Timba Gading, Desa Biluk Petung dan Desa Sembalun Bumbung. Kelompok guru yang ditargetkan untuk mengikuti kegiatan ini adalah para guru sekolah yang sudah seleksi terlebih dahulu, yaitu para guru yang memiliki pemahaman dasar tentang bagaimana mengoperasikan komputer dan pemahaman tentang 
Permana, B. A. C., Bahtiar, H., Sutriandi, A. E., Djamaluddin, M., Suhartini, S. (2021). Pelatihan pemanfaatan teknologi sebagai media pendukung pembelajaran untuk guru di Kecamatan Sembalun. ABSYARA: Jurnal Pengabdian Pada Masyarakat, 2(2), $230-238$. Doi: $10.29408 / a b . v 2 i 2.4210$

penggunaan internet. Pertimbangan dalam proses seleksi ini adalah untuk mempermudah kegiatan pelatihan karena keterbatasan waktu, sehingga akan sulit proses pelaksanaannya apabila guru yang mengikuti pelatihan tidak memiliki pemahaman tentang bagaimana mengoperasikan komputer dan cara menggunakan internet

\section{Prosedur pelaksanaan}

Kegiatan pelatihan untuk peningkatan kompetensi guru dalam hal pembuatan media pembelajaran ini merupakan kegiatan pengabdian masyarakat (PKM) dengan melalui beberapa tahapan kegiatan mulai dari pencarian lokasi pelaksanaan, meminta izin penggunaan lokasi kegiatan, menyusun materi yang akan digunakan saat pelatihan, persiapan kebutuhan jaringan internet sebagai penunjang kegiatan. Yang terlibat dalam kegiatan Pengabdian Masyarakat ini tidak hanya dosen saja akan tetapi mahasiswa juga dilibatkan untuk terjun langsung melalui berbagai tahapan kegiatan hingga pelaksanaan kegiatan diselenggarakan. Kegiatan yang paling pokok dari seluruh rangkaian proses yang dilalui adalah memberi pelatihan kepada para guru di kecamatan Sembalun tentang bagaimana membuat media pembelajaran sebagai penunjang kegiatan belajar mengajar guru di lingkungan kecamatan Sembalun. Secara lebih rinci tahapan kegiatan yang dilalui dalam pelaksanaan pengabdian masyarakat ini adalah :

1. Penentuan Lokasi Kegiatan

Kegiatan dilaksanakan di Kecamatan Sembalun Lombok Timur yang diikuti oleh para guru yang sudah terseleksi di masing-masing desa bagian dari Kecamatan Sembalun. Lokasi SMP 1 Sembalun dipilih sebagai lokasi pelaksanaan kegiatan karena lokasi ini merupakan pusat pendidikan sehingga dianggap layak dan cocok dijadikan sebagai tempat untuk melakukan pelaksanaan kegiatan. Terlebih lagi beberapa siswa dan dosen memiliki hubungan yang baik dengan guru sekolah di SMP 1 karena siswa sedang melakukan KKN di Kecamatan Sembalun.

2. Koordinasi dengan mitra

Sebelum kegiatan pengabdian masyarakat ini dilaksanakan, dilakukan koordinasi dengan mitra yaitu 6 Desa di Kecamatan Sembalun yang terdiri dari Sembalun, Sembalun Lawang, Biluk Petung, Timba Gading, Sajang dan Sembalun Bumbung. Koordinasi yang dilakukan berupa menghubungi masing-masing desa melalui bantuan Kepala Desa untuk mengetahui siapa saja para guru yang dianggap dapat ikut berpartisipasi dalam kegiatan pelatihan peningkatan kompetensi guru dalam bidang teknologi informasi ini.

3. Pelaksanaan Pelatihan

Pelaksanaan pelatihan sendiri dilakukan pada tanggal 28 Agustus 2021 yang dihadiri oleh peserta berasal dari 6 Desa di Kecamatan Sembalun yang masing-masing desa diwakili oleh para guru yang sudah terdaftar memiliki kemampuan dasar komputer dan kemampuan dasar internet. Pelaksanaan pelatihan dipandu oleh Dosen dari Universitas Hamzanwadi dan dibantu oleh mahasiswa dan mahasiswi untuk mendampingi para guru jika mengalami kesulitan selama pelaksanaan kegiatan.

4. Pendampingan

Saat pelaksanaan kegiatan masing-masing peserta diberikan modul untuk dapat dipelajari setelah selesai kegiatan sehingga para guru yang telah mengikuti kegiatan pelatihan peningkatan kompetensi dalam bidang teknologi bisa tetap belajar melalui 
Permana, B. A. C., Bahtiar, H., Sutriandi, A. E., Djamaluddin, M., Suhartini, S. (2021). Pelatihan pemanfaatan teknologi sebagai media pendukung pembelajaran untuk guru di Kecamatan Sembalun. ABSYARA: Jurnal Pengabdian Pada Masyarakat, 2(2), $230-238$. Doi: $10.29408 / a b . v 2 i 2.4210$

panduan modul yang telah diberikan oleh pemateri. Jika para guru mengalami kesulitan setelah pelaksanaan pelatihan maka bisa meminta bantuan pada mahasiswa yang sudah di tunjuk sebagai pendamping untuk melakukan pendampingan lanjutan. Namun jika mahasiswa tidak bisa menyelesaikan permasalahan guru bisa langsung berkonsultasi dengan narasumber melalui sosial media yang diberikan saat pelaksanaan kegiatan.

Sebelum hari pelaksanaan kegiatan pelatihan, pada laptop yang akan digunakan masing-masing guru dipastikan bahwa terdapat aplikasi Power Point, karena nantinya aplikasi tersebut akan digunakan pada pelatihan untuk membuat suatu bahan ajar interaktif. Hal ini mengingat pentingnya media pembelajaran interaktif sebab proses pembelajaran merupakan interaksi dua arah antara guru dengan siswa melalui komunikasi yang aktif dari keduanya (Syahroni dkk., 2020). Dengan bantuan siswa yang dikerahkan di masing-masing desa di kecamatan Sembalun sangat membantu untuk memastikan ketersediaan laptop yang akan digunakan, kesiapan peserta serta kebutuhan software yang akan digunakan pada saat pelatihan. Selain itu para guru diminta untuk mempersiapkan bahan ajar yang dimiliki untuk mempermudah pelaksanaan pelatihan.

\section{HASIL DAN PEMBAHASAN}

HASIL

Kegiatan pengabdian ini berupa pelatihan yang ditujukan bagi para guru untuk meningkatkan kompetensi para guru khususnya yang berada dilingkungan Kecamatan Sembalun dalam hal teknologi, khususnya tentang bagaimana membuat media pembelajaran untuk menunjang kegiatan belajar mengajar di sekolah. Peserta berjumlah 36 orang yang terdiri dari para guru sekolah yang berasal dari 6 Desa di Kecamatan Sembalun. Pertemuan yang dilakukan menggunakan metode ceramah, demonstrasi, latihan, dan tanya jawab beberapa metode yang digunakan tersebut mengadopsi metode yang sebelumnya pernah digunakan pada pengabdian kepada masyarakat sebelumnya yang juga melakukan peningkatan kompetensi guru melalui pembuatan media pembelajaran yang inovatif (Astriani \& Alfahnum, 2020). Para guru yang sudah terdaftar untuk mengikuti pelatihan diwajibkan untuk melakukan registrasi ulang sehingga pelaksana kegiatan bisa mengetahui siapa saja guru - guru dan sekolah yang ikut berpartisipasi untuk kegiatan pengabdian ini .

Hasil yang didapatkan dengan adanya pengabdian kepada masyarakat berupa pelatihan peningkatan kompetensi guru sekolah dalam bidang teknologi di desa Sembalun sebagaimana yang ditunjukkan oleh tabel 1 :

Tabel 1. Hasil Kegiatan Pengabdian Masyarakat

\begin{tabular}{llll}
\hline No. Waktu & Kegiatan & Peserta & Hasil \\
Kegiatan & & \\
\hline
\end{tabular}

\begin{tabular}{llll}
\hline 1 Agustus 2021 & Rapat Persiapan Kegiatan & Dosen & SMP 1 Sembalun \\
& Pelatihan peningkatan & & sebagai lokasi kegiatan \\
& kompetensi guru dibidang & & pelatihan \\
& IT &
\end{tabular}

IT 
Permana, B. A. C., Bahtiar, H., Sutriandi, A. E., Djamaluddin, M., Suhartini, S. (2021). Pelatihan pemanfaatan teknologi sebagai media pendukung pembelajaran untuk guru di Kecamatan Sembalun. ABSYARA: Jurnal Pengabdian Pada Masyarakat, 2(2), $230-238$. Doi: $10.29408 / a b . v 2 i 2.4210$

\begin{tabular}{llll}
\hline 2 Agustus 2021 & $\begin{array}{l}\text { Koordinasi dengan pihak } \\
\text { kecamatan }\end{array}$ & Dosen & $\begin{array}{l}\text { Pihak kecamatan } \\
\text { bersedia untuk }\end{array}$ \\
& Pihak & membantu \\
& Kecamatan & berkoordinasi dengan \\
& & desa untuk seleksi guru \\
& & yang ikut dalam \\
& & pelatihan
\end{tabular}

\begin{tabular}{llll}
\hline $3 \quad$ Agustus 2021 & Koordinasi dengan & Dosen & Mahasiswa membantu \\
& mahasiswa yang berada di & & mempersiapkan \\
& Sembalun & Mahasiswa & kebutuhan perangkat \\
& & lunak, mendata guru \\
& & yang akan mengikuti \\
& & pelatihan dan \\
& & membantu \\
& & mempersiapkan lokasi
\end{tabular}

\begin{tabular}{|c|c|c|c|c|}
\hline 4 & Agustus 2021 & Mengecek Persiapan Lokasi & $\begin{array}{l}\text { Dosen } \\
\text { Mahasiswa }\end{array}$ & $\begin{array}{l}\text { Memasang banner } \\
\text { kegiatan dan } \\
\text { perlengkapan kegiatan } \\
\text { pelatihan di SMP 1 } \\
\text { Sembalun }\end{array}$ \\
\hline 5 & Agustus 2021 & Pelaksanaan Kegiatan & $\begin{array}{l}\text { Dosen } \\
\text { Guru } \\
\text { sebanyak } \\
36 \text { orang } \\
\text { dan } \\
\text { Mahasiswa }\end{array}$ & $\begin{array}{l}\text { Terbentuk pemahaman } \\
\text { guru sekolah tentang } \\
\text { bagaimana membuat } \\
\text { suatu media } \\
\text { pembelajaran yang } \\
\text { menarik menggunakan } \\
\text { aplikasi yang ada pada } \\
\text { MS. Office }\end{array}$ \\
\hline 6 & Agustus 2021 & Evaluasi & Tim Dosen & $\begin{array}{l}\text { Sebagian guru sudah } \\
\text { mampu memanfaatkan } \\
\text { teknologi yang } \\
\text { disediakan pada MS. } \\
\text { Office untuk membuat } \\
\text { media pembelajaran } \\
\text { yang menarik. }\end{array}$ \\
\hline
\end{tabular}

Pelatihan pada pengabdian ini menghasilkan sebuah media pembelajaran interaktif yang dapat digunakan para guru untuk dijadikan sebagai bahan ajar ketika mengajar dikelas. Dengan adanya kompetensi guru untuk menghasilkan media pembelajaran interaktif sangat membantu untuk dapat menghadirkan kegiatan belajar yang berbeda dari biasanya yang hanya 
Permana, B. A. C., Bahtiar, H., Sutriandi, A. E., Djamaluddin, M., Suhartini, S. (2021). Pelatihan pemanfaatan teknologi sebagai media pendukung pembelajaran untuk guru di Kecamatan Sembalun. ABSYARA: Jurnal Pengabdian Pada Masyarakat, 2(2), $230-238$. Doi: $10.29408 / a b . v 2 i 2.4210$

penjelasan-penjelasan materi secara verbal. Dengan bantuan pemanfaatan teknologi ini penyajian materi pelajaran menjadi lebih menarik, dan kompetensi guru dalam memanfaatkan teknologi yang ada menjadi lebih terasah.

Guru bisa mengembangkan kreasinya dalam menyajikan materi menjadi tampilan visual yang tidak monoton dan tidak membosankan dan lebih efisien dalam penggunaan dibandingkan hanya menggunakan slide power point pada umumnya, yang biasanya untuk menuju page tertentu haru dilakukan secara manual. Tetapi melalu pelatihan ini para guru diajarkan bagaimana memanfaatkan penggunaan link antar halaman sehingga jika ingin berpindah halaman cukup melakukan klik tombol saja.

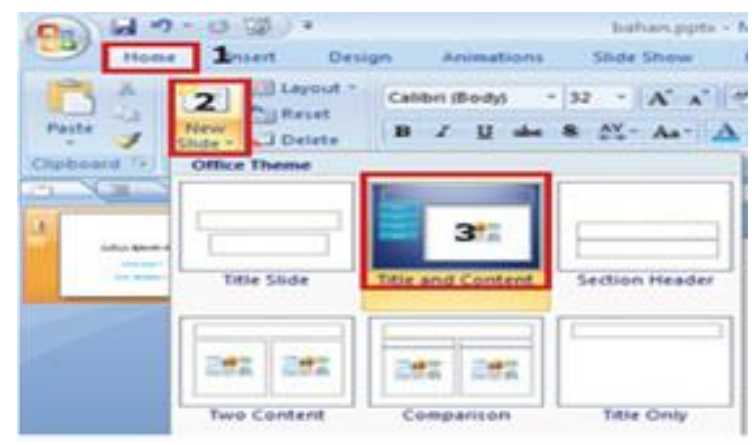

Gambar 1. Teknik dasar membuat media pembelajaran interaktif

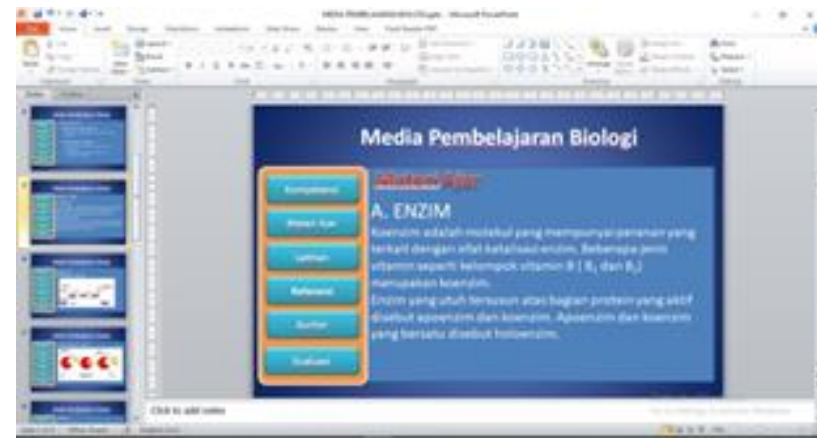

Gambar 2. Contoh media pembelajaran interaktif yang dihasilkan

Berikut adalah dokumentasi sebelum kegiatan pelatihan terlaksana:

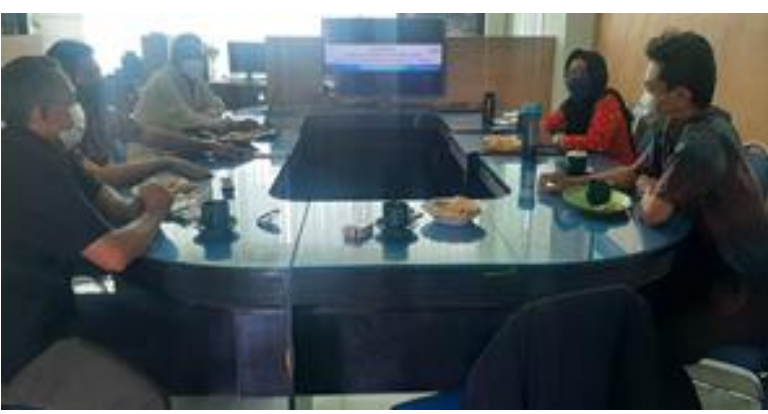

Gambar 3. Rapat persiapan kegiatan

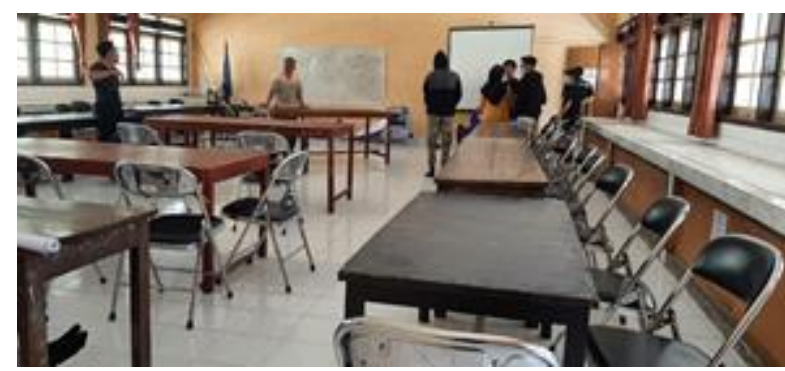

Gambar 5. Persiapan Kegiatan

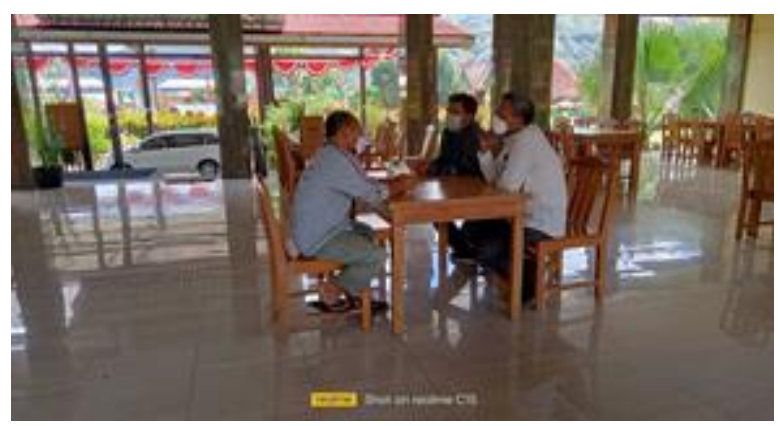

Gambar 4. Koordinasi dengan Kecamatan

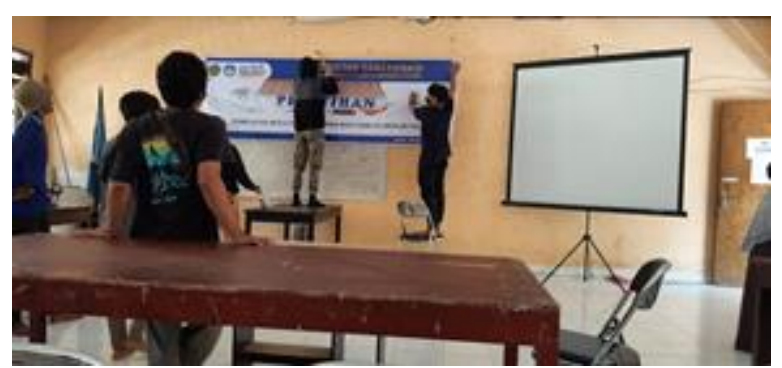

Gambar 6. Pemasangan Banner 
Permana, B. A. C., Bahtiar, H., Sutriandi, A. E., Djamaluddin, M., Suhartini, S. (2021). Pelatihan pemanfaatan teknologi sebagai media pendukung pembelajaran untuk guru di Kecamatan Sembalun. ABSYARA: Jurnal Pengabdian Pada Masyarakat, 2(2), $230-238$. Doi: $10.29408 / a b . v 2 i 2.4210$

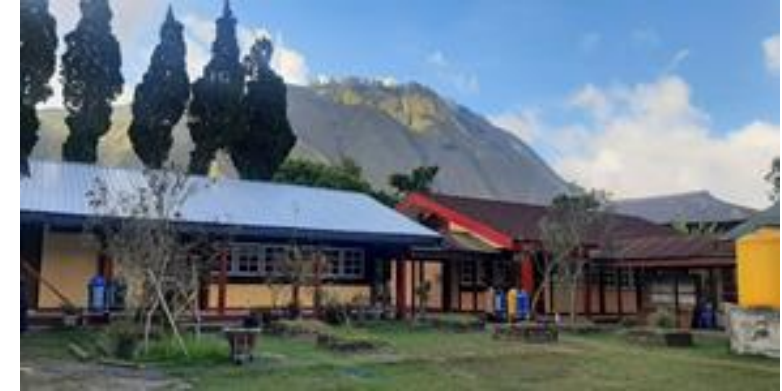

Gambar 7. SMP 1 Sembalun

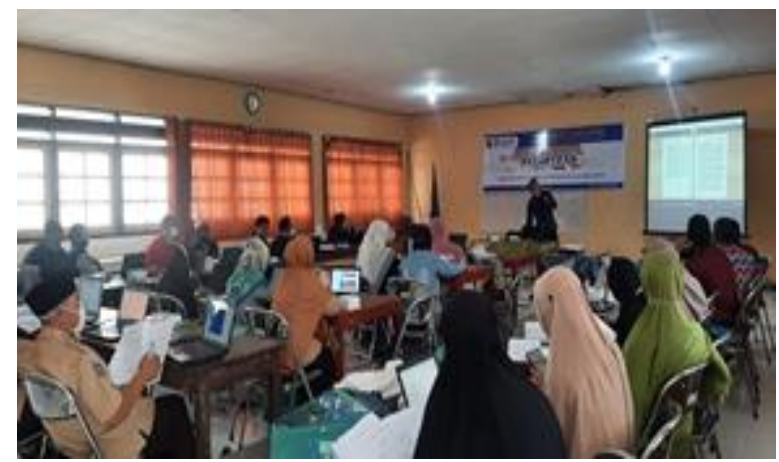

Gambar 9. Peserta kegiatan

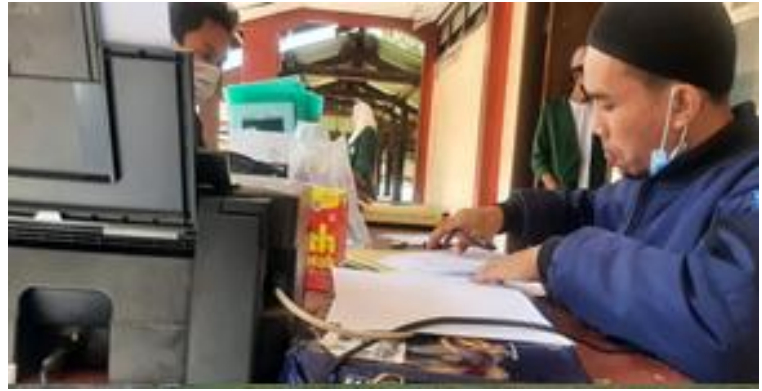

Gambar 8. Registrasi Peserta

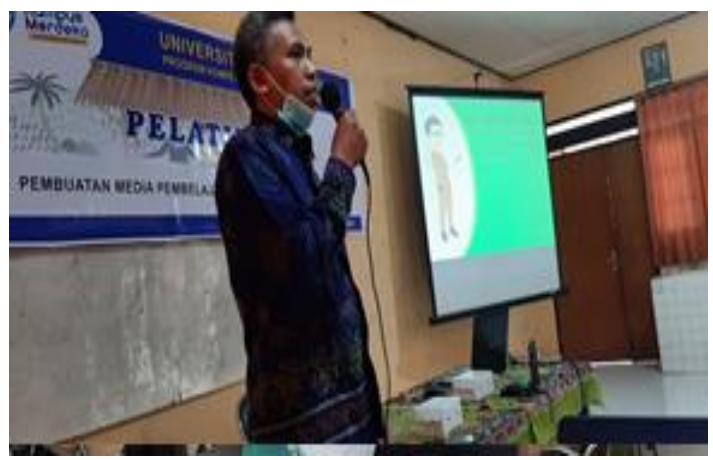

Gambar 10. Penyampaian materi oleh narasumber.

Dari kegiatan pelatihan yang telah dilaksanakan, dari sisi pelaksanaan kegiatan berjalan dengan cukup baik, beberapa kendala yang dialami saat melakukan pelatihan diantaranya koneksi internet yang lambat karena sinyal yang diperoleh tidak begitu baik sehingga untuk melakukan download ataupun searching para guru harus bergantian. Hal tersebut berakibat pada waktu pelaksanaan kegiatan menjadi semakin lama karena butuh waktu untuk mendapatkan koneksi internet yang baik. Kendala ini memang tidak dapat dihindari mengingat kondisi geografis di Sembalun yang masuk dalam area pegunungan.

Selebihnya kegiatan pelatihan berjalan lancar terlebih lagi kegiatan ini melibatkan mahasiswa untuk mendampingi para guru, sehingga ketika ada kendala atau ada hal- hal yang kurang dipahami guru bisa langsung meminta bantuan mahasiswa serta dosen yang bertugas sebagai pendamping. Sementara narasumber bisa tetap melanjutkan materinya sehingga guru yang sudah paham bisa tetap melanjutkan dan bagi guru yang belum paham tetap bisa mengikuti. Selain itu selama kegiatan pelatihan dilaksanakan, para guru terlihat antusias untuk mengikuti pelatihan ini. Hal ini dapat dilihat dari jumlah guru yang tetap datang untuk mengikuti kegiatan pagi hari dan siang hari walaupun saat pelatihan berlangsung ada jeda istirahat makan siang dan Shalat.

\section{PEMBAHASAN}

Kegiatan pengabdian ini dilaksanakan dengan tujuan peningkatan kompetensi guru dalam membuat suatu media pembelajaran berbasis teknologi sehingga kreativitas guru menjadi lebih terasah dan para guru khususnya yang tinggal di desa bisa beradaptasi dengan perkembangan teknologi saat ini. Dalam pelaksanaan pelatihan, masih ada guru yang sedikit kesulitan dalam pelatihan untuk pengoperasian MS. Power Point walaupun dari peserta yang terpilih mengikuti pelatihan adalah guru-guru yang sudah tidak awam dengan komputer. Hal 
Permana, B. A. C., Bahtiar, H., Sutriandi, A. E., Djamaluddin, M., Suhartini, S. (2021). Pelatihan pemanfaatan teknologi sebagai media pendukung pembelajaran untuk guru di Kecamatan Sembalun. ABSYARA: Jurnal Pengabdian Pada Masyarakat, 2(2), $230-238$. Doi: $10.29408 / a b . v 2 i 2.4210$

ini kemungkinan dikarenakan karena sebagian guru - guru yang mengikuti pelatihan tergolong sudah berumur. Hal lain juga kemungkinan karena durasi waktu yang dilakukan untuk pelaksanaan kegiatan pelatihan ini tidak cukup lama, namun hal tersebut dapat diatasi dengan pemberian modul kegiatan yang sudah dipersiapkan oleh panitia kegiatan dengan merujuk dari pengalaman kegiatan yang juga pernah dilakukan oleh kegiatan pengabdian sebelumnya yang juga bertujuan untuk peningkatan kompetensi guru (Anita, dkk., 2016).

Tahap evaluasi yang selanjutnya dilakukan adalah pemantauan berkelanjutan yang dilakukan melalui bantuan mahasiswa yang sedang berada di Sembalun dan keterbukaan para dosen untuk dihubungi oleh para guru jika ada kendala dan kesulitan terkait materi pelatihan yang sebelumnya sudah diberikan. Temuan yang didapatkan selama berjalannya proses pelatihan adalah bahwa tidak semua guru di sekolah mampu memanfaatkan teknologi untuk pembelajaran, karena tidak semua guru memiliki komputer. Sebagian yang menggunakan teknologi komputer adalah yang sudah paham pengoperasian komputer, namun sebagian besar masih menggunakan teknik manual yaitu verbal dan buku.

\section{SIMPULAN}

Pelaksanaan kegiatan pengabdian ini dapat dikatakan telah tercapai karena sebagian besar dari para guru yang telah hadir mengikuti kegiatan pelatihan berhasil membuat suatu media pembelajaran interaktif sesuai dengan mata pelajaran yang diampu di sekolah. Kepala sekolah dan camat setempat juga sangat antusias dengan kegiatan ini dan berharap kegiatan ini tetap berlanjut dan ada kegiatan-kegiatan serupa yang akan diadakan di lain waktu sehingga pemerataan keterampilan dan kemampuan para guru di Sembalun tidak kalah dengan guruguru di kota.

\section{PERNYATAAN PENULIS}

Pernyataan tentang bahwa artikel yang dibuat belum pernah dipublikasi pada jurnal yang lain

\section{DAFTAR PUSTAKA}

Anita, N., Puspitasari, T. D., \& Habibi, A. (2016). Pengembangan Dan Peningkatan Kompetensi Guru Dalam Membuat Media Pembelajaran. Prosiding, 164-167

Astriani, M. M., \& Alfahnum, M. (2020). Peningkatan Kompetensi Guru Paud dalam Mengembangkan Media Pembelajaran Inovatif. Jurnal PKM: Pengabdian kepada Masyarakat Vol, 3(04). https://doi.org/10.30998/jurnalpkm.v3i4.8151

Elizabeth, T., Pratama, D., Alamsyah, D., Yoannita, Y., Inayatullah, I., \& Tinaliah, T. (2021). Pelatihan aplikasi screen recorder dan video conference guna meningkatkan proses belajar mengajar. ABSYARA: Jurnal Pengabdian Pada Masyarakat, 2(1), 49-55.

Kholisho, Y. N., Arianti, B. D. D., Jamaluddin, J., Wirasasmita, R. H., Ismatulloh, K., Uska, M. Z., \& Fathoni, A. (2021). Pelatihan pembuatan dan editing video bagi guru SD untuk menghadapi Era Industri 4.0. ABSYARA: Jurnal Pengabdian Pada Masyarakat, 2(1), 119-127. https://doi.org/10.29408/ab.v2i1.3586

Miftah, M. (2014). Pemanfaatan media pembelajaran untuk peningkatan kualitas belajar siswa. Kwangsan, 2(1), 286949. 
Permana, B. A. C., Bahtiar, H., Sutriandi, A. E., Djamaluddin, M., Suhartini, S. (2021). Pelatihan pemanfaatan teknologi sebagai media pendukung pembelajaran untuk guru di Kecamatan Sembalun. ABSYARA: Jurnal Pengabdian Pada Masyarakat, 2(2), $230-238$. Doi: $10.29408 / a b . v 2 i 2.4210$

Myori, D. E., Hidayat, R., Eliza, F., \& Fadli, R. (2019). Peningkatan Kompetensi Guru dalam Penguasaan Teknologi Informasi dan Komunikasi melalui Pelatihan Pengembangan Media Pembelajaran Berbasis Android. JTEV (Jurnal Teknik Elektro Dan Vokasional), 5(2), 102-109.

Samsuri, T., Muliadi, A., Muhali, M., Asy'ari, M., Prayogi, S., \& Hunaepi, H. (2020). Pelatihan desain media interaktif pada pembelajaran daring bagi dosen pendidikan biologi. ABSYARA: Jurnal Pengabdian Pada Masyarakat, 1(2), 64-69. https://doi.org/10.29408/ab.v1i2.2745

Soemantri, S. (2019). Pelatihan Membuat Media Pembelajaran Digital. Aksiologiya: Jurnal Pengabdian Kepada Masyarakat, 3(1), 64-69.

Sutisna, U., Elkarimah, M. F., \& Asma, F. R. (2020). Pengembangan kompetensi profesional guru PAI melalui pemanfaatan teknologi informasi. ABSYARA: Jurnal Pengabdian Pada Masyarakat, 1(2), 43-48. https://doi.org/10.29408/ab.v1i2.2629

Syahroni, M., Dianastiti, F. E., \& Firmadani, F. (2020). Pelatihan Media Pembelajaran Berbasis Teknologi Informasi untuk Meningkatkan Keterampilan Guru dalam Pembelajaran Jarak Jauh. International Journal of Community Service Learning, 4(3), 170-178.

Wardinur, W., \& Mutawally, F. (2019). Peningkatan Kompetensi Guru Melalui Pelatihan Pemanfaatan Teknologi sebagai Media Pendukung Pembelajaran di MAN 1 Pidie. Jurnal Sosiologi USK (Media Pemikiran \& Aplikasi), 13(2), 167-182.

Wijaya, F., \& Ferdinandus, S. (2020). Pelatihan Pembuatan Dan Pengelolaan WebBlog bagi Guru-Guru Smp Negeri 10 Ambon Sebagai Media Pembelajaran Yang Efektif. JURNAL PENGABDIAN MASYARAKAT JAMAK, 3(1), 217-223. 